\title{
Depression and HIV associated neurocognitive disorders among HIV infected adults in rural southwestern Uganda: a cross-sectional quantitative study
}

\author{
Jane Kasozi Namagga ${ }^{1 *}$, Godfrey Zari Rukundo², Vallence Niyonzima ${ }^{1}$ and Joachim Voss ${ }^{3}$
}

\begin{abstract}
Background: HIV-Associated Neurocognitive Disorder (HAND remains a pronounced consequence of HIV/AIDS despite improved life expectancies. This is often associated with several dysfunctions such as decrease of attention, mood alterations and psychomotor disturbances. Many factors, including age, gender, employment status, and psychiatric disorders, have been associated with HAND. Among the associated psychiatric disorders, depression is often more prevalent. It can influence not only quality of life, relationships and employment but also adherence to medical care. We assessed the prevalence of depression and its association with HAND among people living with HIV in rural Southwestern Uganda.

Methods: This was a cross-sectional study that used Beck Depression Inventory-1 and International HIV Dementia Scale to assess depression and HAND respectively. We defined depression with a score of $>10$ and HAND with a cutoff score of $\leq 10$. We conducted data analysis using STATA version 12, and Pearson Chi-square test and logistic regression to determine associations between depression and HAND. The level of statistical significance was set at $p \leq 0.05$. Ethical approval and administrative clearance were obtained from relevant bodies.
\end{abstract}

Results: Of the 393 participants assessed for depression and HAND, 27\% had depression and 58.3\% screened positive for HAND. All levels of depression were more prevalent among female participants. We found a significant association between depression and HIV associated neurocognitive disorders (X2 (3) $=9.0538 p=0.029)$.

Conclusion: Our findings confirmed a high prevalence of depression in individuals with HAND which is a major component of the disease burden.

Keywords: Beck depression inventory-1, Depression, HIV-associated neurocognitive disorder, International HIV dementia scale

\footnotetext{
* Correspondence: jkasozi@must.ac.ug

${ }^{1}$ Department of Nursing, Faculty of Medicine, Mbarara University of Science and Technology, Mbarara, Uganda

Full list of author information is available at the end of the article
}

(c) The Author(s). 2021 Open Access This article is licensed under a Creative Commons Attribution 4.0 International License, which permits use, sharing, adaptation, distribution and reproduction in any medium or format, as long as you give appropriate credit to the original author(s) and the source, provide a link to the Creative Commons licence, and indicate if changes were made. The images or other third party material in this article are included in the article's Creative Commons licence, unless indicated otherwise in a credit line to the material. If material is not included in the article's Creative Commons licence and your intended use is not permitted by statutory regulation or exceeds the permitted use, you will need to obtain permission directly from the copyright holder. To view a copy of this licence, visit http://creativecommons.org/licenses/by/4.0/ The Creative Commons Public Domain Dedication waiver (http://creativecommons.org/publicdomain/zero/1.0/) applies to the data made available in this article, unless otherwise stated in a credit line to the data. 


\section{Background}

Worldwide, the increasing access and use of HIV treatment has brought a dramatic change in the demographics of people living with HIV (PLWH) [1]. This has increased their longevity [2]. HIV infection targets the central nervous system in subcortical brain areas, causing brain impairment [3]. This increases the patients' risk for various neurocognitive disorders such as HIVAssociated Neurocognitive Disorders (HAND) [4]. HAND is defined as impairment of multiple cognitive domains in association with HIV in the absence of other causes [5, 6]. Many factors, including age, gender, employment status and psychiatric disorders, have been associated with HAND. Among psychiatric disorders, depression is often more prevalent [7]. According to International statistical classification of diseases and related health problems (ICD) \& Diagnostic and Statistical Manual of Mental Disorders, Fifth Edition (DSM-5), depression is defined as a mood disorder characterized by persistently low mood, a feeling of sadness and hopelessness and loss of interest in activities they once enjoyed $[8,9]$.

Several adverse outcomes are associated with depression such as failure to adhere to recommended medical care, diet, exercise, impaired functional status, reduced quality of life, increased morbidity and mortality [7, 1012]. However, insufficient attention has been paid to psychiatric conditions in HIV population in sub-Saharan Africa (SSA) notably in Uganda where most PLWH live and are in care [13].

Some studies in Zimbabwe and Kenya revealed that depression among PLWH is associated with poor health status, faster progression to AIDS and increased mortality $[13,14]$. Furthermore, depression leads to reduced economic productivity and working abilities, social isolation and difficulties in problem solving [13]. According to Memiah, Shumba [15] and Wroe, Hedt-Gauthier [16], depression has been shown to predict non-adherence to ART.

A study by Nel and Kagee [17] in South Africa reported that non-adherent patients had a 3-fold higher risk of presenting moderate to severe depressive symptoms in comparison to adherent patients. The current study assessed the prevalence of depression and its association with HAND among HIV infected adults in rural southwestern Uganda.

\section{Materials and methods Study area}

The study was conducted at The AIDS Support Organization (TASO) in Mbarara and Rukungiri districts in southwestern Uganda. TASO is the largest NonGovernmental Organization that provides comprehensive HIV/AIDS care that includes: HIV voluntary counseling and testing (VCT), antiretroviral therapy (ART) for adults and pediatric patients, prevention of maternal to child transmission (PMTCT), testing and routine laboratory services, including viral load testing. The TASO care management model is focused on individual patient, tailored to medication adherence, disease monitoring, and emphasizes home based care [18]. These services are delivered through community drug distribution points (CDDP) and /or at TASO centres and community outreaches.

\section{Study design}

A cross-sectional study was conducted between April and July, 2017 among people living with HIV (PLWH) attending TASO centres in Southwestern Uganda. This provided a snapshot of the prevalence of depression and its association with HAND over a short period of time within these centres.

\section{Study procedures and data collection}

The sample size was calculated by a mathematical expression, $\mathrm{N}=\mathrm{Z}^{2} \mathrm{PQ} / \mathrm{D}^{2}$ (Lwanga \& Yook, 1986), where: $\mathrm{N}=$ Sample size, $\mathrm{Z}=$ Normal distribution at 1.96 that corresponds to $95 \%$ confidence interval, $P=50 \%(0.5)$ is the estimated proportion in the target population with depression, $\mathrm{D}=$ Margin of errors allowed which correspond to 0.05 error, $\mathrm{Q}=$ Estimated proportion without depression $(1-\mathrm{p})=50 \%(0.5)$.

$N=1.96^{2 * 0} 0.5^{*} 0.5 / 0.05^{2}=384.16$. The calculated sample was 384 participants and we added 9 participants to compensate for any missing data. Our total sample was 393 participants.

We consecutively enrolled 393 participants on clinic days that willingly participated, giving a response rate of $100 \%$. Recruitment was done by the first author (JKN) and trained research assistants (RAs). Prior to data collection, the RAs were trained by a psychiatrist to gain confidence and competence. Additionally the RAs were fluent in English and Runyakitara (the local language) understood by the participants. A written informed consent was obtained from the participants preceding to participation. Recruitment was pursued until the calculated sample size of 393 was reached. Permission to review the patients' medical records was sought from the participants and directors of the study sites.

We included PLWH who were on ART and were between 18 and 50 years old. We excluded individuals who were above 50 years or older since old age is a known risk factor for cognitive impairments [19]. Evidence shows that the risk of experiencing depression increases with age due to some natural body changes such as folate deficiency [20]. Folic acid is important for the nervous system functioning and its deficiency affects mood and cognitive function, especially in older people. To ensure that there were no other obvious causes of 
depression other than HIV; we further excluded those individuals that had a history of depression and other chronic illnesses before HIV infection to minimize confounding factors. The functional impairment associated with medical illnesses often causes depression [21]. These included; 1) opportunistic infections of the central nervous system (CNS), 2) regular substance abuse, 3) a positive diagnosis of schizophrenia 4) thyroid dysfunction, 5) diabetes mellitus and/or hypertension, and 6) the deaf 7) mentally disabled and 8) pregnant women.

\section{Data collection instruments}

The Beck Depression Inventory Scale I (BDI- I) and International HIV Dementia Scale (IHDS were used to screen depression and HAND among study participants respectively. Though, the tools have been tested and validated [20, 21], they are subjective scales used for screening purposes, which have to be further evaluated to confirm the diagnosis.

The Beck Depression Inventory (BDI) is a 21-item measure that is most widely used for screening the severity of depression [22]. The inventory is composed of items relating to depressive symptoms such as hopelessness and irritability, cognitions like guilt or feelings of being punished, as well as physical symptoms; fatigue, weight loss, and lack of interest in sex. Each item had four responses ranging in intensity from 0 to 3 giving a total possible score ranging from 0 to 63 . This was computed and compared to the key scale to determine the severity of depression. A score of 0-9 suggested absence or minimal depressive symptoms whereas scores from 10 to $18,19-29$, and $30-63$ were suggestive of the presence of mild or moderate, and severe depressive symptoms respectively. Therefore a score $<10$ means no depression while a score $\geq 10$ mean presence of depressive symptoms. The BDI-1 has been used in many studies to evaluate depression levels among different populations that include SSA, China, Portugal, and Brazil [23-26].

According to Beck, Ward [27] and Beck, Steer [28], BDI-1 was introduced in 1961 and since then its reliability and validity have been established across a broad spectrum of clinical and non-clinical populations.

The HIV associated neurocognitive disorder was screened using Sacktor's IHDS [29]. This tool consists of three parts-motor speed, psychomotor speed, and memory. Each part assesses a specific cognitive domain and scores up to a maximum of four points. The final score is the sum of the three sub-scores with a range from 0 to12points. Motor speed was assessed through finger tapping, psychomotor speed through a defined alternating hand sequence, and memory recall through a 4 word recall after the first two assessments are performed. The IHDS has been validated for screening HAND in the
United States, Uganda, Ethiopia, Argentina and South Africa [29, 30]. The tool has been recommended for use in research studies because it is easy to administer by all trained health workers. Another advantage of the IHDS is, that its administration requires no sophisticated instrumentation other than a watch with a second hand, and the instrument is independent of language and culture.

The BDI-1 and IHDS were translated into Runyakitara which is the predominant language spoken by the participants and back translated to English in order to maintain the original meaning. An additional sociodemographic questionnaire was designed to elicit demographic information including age, gender, education, occupation and other demographic variables.

\section{Statistical analysis}

Data were entered and analyzed using STATA version 12 and presented using descriptive statistics. Chi square, Univariate and multivariate logistic regression analyses were performed to determine the association between depression and HAND with the level of statistical significance set at $p \leq 0.05$.

\section{Results}

Of the 393 that participated in the study, 105 (26.7\%) were males and $288(73.3 \%)$ were females. The demographic characteristics of the participants are presented in Table 1 below:

The Chi square analysis showed that education level $\left(\chi^{2}(15)=28.2 p=0.02\right)$ and marital status $\left(\chi^{2}(15)=28.7\right.$ $p=0.018)$ were associated with depression respectively. Religion, age and employment were not associated with depression. One way ANOVA revealed that the divorced were more associated with depression $(\mathrm{F}(6,388)=2.82$, $p=.0108)$. Similarly, participants with secondary $(p=$ $0.018)$ and tertiary education level $(p=0.042)$ were more associated with depression compared to those without formal education.

Table 2 shows the depression classification of the participants who were living with HIV.

The results show that there is a statistical significant difference between the four classifications of depression $(\chi 2(3)=9.63, p=0.022)$. Majority $(73.0 \%)$ of the participants had minimal depression and out of these, $22.4 \%$ were males and $50.6 \%$ females. The minority had moderate $(0.3 \%$ males and $3.5 \%$ females) and severe depression $(0.3 \%$ males and $0.5 \%$ females) respectively. The prevalence of depression was found to be $27 \%$, higher in females $(22.6 \%)$ than males $(4.4 \%)$.

\section{Determinants of depression}

Logistic regression analysis was conducted to determine the risk factors associated with depression (Table 3). 
Table 1 Association between demographic characteristics and depression

\begin{tabular}{|c|c|c|c|c|c|c|c|}
\hline \multirow{2}{*}{$\begin{array}{l}\text { Demographic } \\
\text { characteristic }\end{array}$} & \multirow{2}{*}{$\begin{array}{l}\text { Total } \\
\text { cohort } \\
n=393 \\
(\%)\end{array}$} & \multicolumn{4}{|c|}{ Depression classification } & \multirow[t]{2}{*}{$x^{2}$} & \multirow{2}{*}{$\begin{array}{l}P \\
\text { value }\end{array}$} \\
\hline & & $\begin{array}{l}\text { Minimal } \\
\text { n (\%) }\end{array}$ & $\begin{array}{l}\text { Mild } \\
\text { n (\%) }\end{array}$ & $\begin{array}{l}\text { Moderate } \\
\mathrm{n}(\%)\end{array}$ & $\begin{array}{l}\text { Severe } \\
\text { n (\%) }\end{array}$ & & \\
\hline \multicolumn{8}{|l|}{ Age } \\
\hline $18-30$ & $84(21.4)$ & $28(68.2)$ & $22(25.9)$ & $4(4.7)$ & $1(1.2)$ & \multirow[t]{3}{*}{3.04} & \multirow[t]{3}{*}{0.80} \\
\hline $31-43$ & $181(46.1)$ & $140(76.9)$ & $35(19.2)$ & $6(3.3)$ & $1(0.6)$ & & \\
\hline $44-50$ & $128(32.5)$ & $90(70.3)$ & $32(25.0)$ & $5(3.9)$ & $1(0.8)$ & & \\
\hline \multicolumn{8}{|l|}{ Marital status } \\
\hline Single & $49(12.5)$ & $32(65.3)$ & 15 (30.6) & $1(2.0)$ & $1(2.0)$ & \multirow[t]{4}{*}{28.7} & \multirow[t]{4}{*}{$0.018^{*}$} \\
\hline Married & $186(47.3)$ & $148(79.6)$ & $33(17.7)$ & $4(2.2)$ & $1(0.5)$ & & \\
\hline Divorced/separated & $58(14.8)$ & $39(67.2)$ & $13(22.4)$ & $6(10.3)$ & $0(0.0)$ & & \\
\hline Widow/widower & $100(25.4)$ & $68(68.0)$ & $28(28.0)$ & $3(3.0)$ & $1(1.0)$ & & \\
\hline \multicolumn{8}{|l|}{ Education level } \\
\hline No formal & $32(8.1)$ & $17(53.1)$ & $11(34.4)$ & $3(9.4)$ & $1(3.1)$ & \multirow[t]{4}{*}{28.2} & \multirow[t]{4}{*}{$0.02^{*}$} \\
\hline Primary & $221(56.2)$ & $163(73.7)$ & $48(21.7)$ & $9(4.1)$ & $1(0.5)$ & & \\
\hline Secondary & $101(25.7)$ & $79(78.2)$ & 19 (18.8) & $3(3.0)$ & $0(0)$ & & \\
\hline Vocational/Tertiary & $39(9.9)$ & $28(71.8)$ & $10(25.6)$ & $0(0.0)$ & $1(2.6)$ & & \\
\hline \multicolumn{8}{|l|}{ Employment } \\
\hline Full time & $129(23.8)$ & $102(79.1)$ & $22(17.1)$ & $5(3.8)$ & $0(0.0)$ & \multirow[t]{5}{*}{23.0} & \multirow[t]{5}{*}{0.34} \\
\hline Part time & $55(14.0)$ & $40(72.7)$ & $10(18.2)$ & $3(5.5)$ & $2(3.6)$ & & \\
\hline Peasant & $178(45.3)$ & $122(68.5)$ & 49 (27.5) & $6(3.4)$ & $1(0.6)$ & & \\
\hline Unemployed & $13(3.3)$ & $7(53.8)$ & $5(38.5)$ & $1(7.7)$ & $0(0.0)$ & & \\
\hline Others & $18(4.6)$ & 16 (88.9) & $2(11.1)$ & $0(0.0)$ & $0(0.0)$ & & \\
\hline \multicolumn{8}{|l|}{ Religion } \\
\hline Anglican & $212(53.9)$ & $151(71.2)$ & 49 (23.1) & $10(4.7)$ & $2(0.9)$ & \multirow[t]{4}{*}{6.4} & \multirow[t]{4}{*}{0.70} \\
\hline Catholic & $131(33.3)$ & $97(74.0)$ & 30 (22.9) & $3(2.3)$ & $1(0.8)$ & & \\
\hline Moslem & $21(5.3)$ & $17(81.0)$ & $2(9.5)$ & $2(9.5)$ & $0(0.0)$ & & \\
\hline Others & $29(7.4)$ & $22(75.9)$ & $7(24.1)$ & $0(0.0)$ & $0(0.0)$ & & \\
\hline
\end{tabular}

*reflects statistically significant results $(P<$ or $=0.05)$

Univariate logistic regression showed that being a female (OR 2.52, $P$ value 0.003 ), age between 44 and 50 (OR 2.01, $P$ value 0.018 ), unemployed (OR 1.76, $P$ value $0.004)$, secondary (OR 1.034, $P$ value 0.04 ) and tertiary education level (OR 1.46, 0.003) and being on second

Table 2 Classification of depression according to sex

\begin{tabular}{llll}
\hline $\begin{array}{l}\text { Depression } \\
\text { classification }\end{array}$ & $\begin{array}{l}\text { Total cohort } \\
\mathbf{n}(\%)\end{array}$ & $\begin{array}{l}\text { Sex } \\
\mathbf{n}(\%)\end{array}$ & \\
\cline { 3 - 4 } & $\mathbf{3 9 3 ( 1 0 0 )}$ & $\begin{array}{l}\text { Male } \\
\mathbf{1 0 5}(\mathbf{2 6 . 7 )}\end{array}$ & $\begin{array}{l}\text { Female } \\
\mathbf{2 8 8}(\mathbf{7 3 . 3})\end{array}$ \\
\hline Minimal & $287(73.0)$ & $88(22.4)$ & $199(50.6)$ \\
Mild & $88(22.4)$ & $15(3.8)$ & $73(18.6)$ \\
Moderate & $15(3.8)$ & $1(0.3)$ & $14(3.5)$ \\
Severe & $3(0.8)$ & $1(0.3)$ & $2(0.5)$ \\
Pearson chi square Value & $X 2(3)=9.63, p=0.022$ & \\
\hline
\end{tabular}

line ART were associated with depression. Multivariate logistic regression showed that age between 44 and 50 (aOR 1.86, $p$ value 0.023 ) and being a female (aOR 2.01 $P$ value 0.005$)$ were associated with depression.

\section{Association between HAND and depression}

The association between HAND and depression are displayed below (Table 4).

The prevalence of HAND was $58.3 \%$. Pearson Chi square test analysis showed that depression was significantly associated with HAND ( $\chi^{2}(3)=9.0538, p=$ 0.029 ).

\section{Discussion}

We aimed to assess the prevalence of depression and its association with HAND among people living with HIV in rural Southwestern Uganda. We found depression prevalence of: $73 \%$ minimal, $22.4 \%$ mild, 3.8 moderate 
Table 3 Univariate and Multivariate logistic regression analysis for determinants of depression

\begin{tabular}{|c|c|c|c|c|c|c|}
\hline \multirow[t]{2}{*}{ Variable } & \multicolumn{3}{|c|}{ Univariate analysis } & \multicolumn{3}{|c|}{ Multivariate analysis } \\
\hline & COR & $95 \% \mathrm{Cl}$ & $P$ value & AOR & $95 \% \mathrm{Cl}$ & $P$ value \\
\hline \multicolumn{7}{|l|}{ Age } \\
\hline $18-30$ & Ref & & & Ref & & \\
\hline $31-43$ & 0.86 & $0.54-0.92$ & 0.132 & 0.56 & $0.32-0.68$ & 0.263 \\
\hline $44-50$ & 2.01 & $1.25-3.20$ & $0.018^{*}$ & 1.86 & $1.36-2.06$ & $0.023^{*}$ \\
\hline \multicolumn{7}{|l|}{ Sex } \\
\hline Male & Ref & & & Ref & & \\
\hline Female & 2.52 & $2.33-2.81$ & $0.003^{*}$ & 2.01 & $1.76-2.51$ & $0.005^{*}$ \\
\hline \multicolumn{7}{|l|}{ Employment } \\
\hline Full time & Ref & & & Ref & & \\
\hline Part time & 0.84 & $0.46-1.47$ & 0.09 & 0.64 & $0.12-0.84$ & 0.106 \\
\hline Peasant & 0.54 & $0.23-1.16$ & 0.12 & 0.44 & $0.014-0.83$ & 0.16 \\
\hline Unemployed & 1.76 & $1.12-2.56$ & $0.004^{*}$ & 0.96 & $0.46-1.98$ & 0.08 \\
\hline \multicolumn{7}{|l|}{ Education Level } \\
\hline No formal education & Ref & & & Ref & & \\
\hline Primary & 0.69 & $0.36-1.34$ & 0.737 & 0.48 & $0.21-1.24$ & 0.42 \\
\hline Secondary & 1.034 & $1.015-2.06$ & $0.04^{*}$ & 0.93 & $0.46-2.30$ & 0.12 \\
\hline Vocational/Tertiary & 1.46 & $1.024-2.98$ & $0.003^{*}$ & 0.84 & $0.28-2.40$ & 0.08 \\
\hline \multicolumn{7}{|l|}{ Drug adverse effect } \\
\hline \multicolumn{7}{|l|}{ Present } \\
\hline Absent & 0.98 & $0.234-1.43$ & 0.46 & & & \\
\hline \multicolumn{7}{|l|}{ Treatment line } \\
\hline First line & Ref & & & & & \\
\hline Second line & 1.70 & $1.24-2.14$ & $0.004^{*}$ & 1.08 & $0.98-1.94$ & 0.069 \\
\hline \multicolumn{7}{|l|}{ Regimen } \\
\hline Non EFV based & Ref & & & & & \\
\hline EFV based & 1.04 & $0.82-1.37$ & 0.067 & & & \\
\hline ART duration & 0.39 & $0.104-1.03$ & 0.069 & & & \\
\hline
\end{tabular}

and $0.8 \%$ severe. In these depressive episodes, the patient suffers from lowering of mood, reduction of energy, and decrease in activity. There is lack of concentration with marked tiredness and reduced capacity for enjoyment and interest in any activity. Sleep is usually disturbed and appetite diminished. Usually, there is absence of self-confidence and self-esteem even in the mild form.
While the mild depressive episode presents with two or three of the above symptoms, the patient is usually distressed but will be able to continue with most activities. The moderate depressive episode presents with four or more of the above symptoms, the patient is likely to have great difficulty in continuing with ordinary activities. With severe depressive episode, several of the above

Table 4 Association between depression and HAND

\begin{tabular}{lllll}
\hline Depression classification & $\begin{array}{l}\text { TOTAL COHORT } \\
\boldsymbol{n}=\mathbf{3 9 3}(\%)\end{array}$ & $\begin{array}{l}\text { HAND } \\
\boldsymbol{n}=\mathbf{2 2 9}(\%)\end{array}$ & $\begin{array}{l}\text { NO HAND } \\
\boldsymbol{n}=\mathbf{1 6 4}(\%)\end{array}$ & Pearson X2 \\
\hline Minimal & $287(73.0)$ & $156(39.7)$ & $131(33.3)$ & $32(3)=9.0538$ \\
Mild & $88(22.4)$ & $58(14.8)$ & $30(7.6)$ & p \\
Moderate & $15(3.8)$ & $13(3.3)$ & $2(0.5)$ & $1(0.3)$ \\
Severe & $3(0.8)$ & $2(0.5)$ & & \\
\hline
\end{tabular}

*reflects statistically significant results $(P<$ or $=0.05)$ 
symptoms are marked and distressing, typically loss of self-esteem and ideas of worthlessness or guilt [8].

In our current study, the overall prevalence of depression was found to be $27 \%$. It was more prevalent in females (22.6\%) than males (4.4\%) and much lower compared to the findings of Kagee and Martin [31] that estimated a prevalence of moderate and severe depression of 37.4 and $20 \%$, respectively. The lower rates may be to the continued use of ART which has improved the health of PLWH. Similarly, studies conducted in Brazil reported a depression prevalence of $32-34 \%[32,33]$ which shows a great association with neurocognitive loss. Though the prevalence of depression in the current study was lower than in other studies in South Africa and Brazil, it could not be neglected. The results suggest that a considerable proportion of PLWH may be experiencing psychiatric difficulty, for which they may not be receiving treatment. Clarke and Currie [34] also asserted that chronic conditions such as HIV are a major risk factor for depression more so in individuals that may be cognitively impaired. Multivariate logistic regression showed age between 44 and 50 (aOR 1.86, $p$ value 0.023 ) and being a female was 2 times more likely to be associated with depression (aOR 2.01 $P$ value 0.005 ). This may probably be due to women being more likely to suffer a greater number of stressful life experiences compared with men. This is in line with the study that reported the prevalence of major depression being higher in women $(5.5 \%)$ than in men (3.2\%) in 2010, representing a 1.7 -fold greater incidence in women $[35,36]$. Studies from developed countries suggest that the differential risk may primarily stem from biological sex differences where estrogen present may be protective in males [37].

With less efficient immune system, older patients receiving ART are at an increased risk of neuropsychological impairment such as depression [38]. With aging, PLWH experience more complications in the physiological and psychological domains of which little attention is given [39]. In sub-Saharan Africa, up to $25 \%$ of PLWH suffer from some of depression [40] and some studies indicate that older age is associated with depressive symptoms coupled with HAND [41] . A recent study has also reported a $24 \%$ increased risk of depression in older PLWH [42] and are more likely to develop viral resistance because of low level of ART adherence.

Conversely, HAND is on increase despite the era of effective antiretroviral therapy. In the present study, out of 393 participants, $58.3 \%$ screened positive for HAND. This is in consistency with other studies that used similar tools to screen for HAND [29, 43]. The associated factors were gender, peasant farming and older age. This agrees with Cross, Önen [10] who reported that sociodemographic factors such as age, gender, occupation, marital status might influence the likelihood of developing HAND.

We found a significant association between depression and HAND. Depression can lead to neurocognitive deficits indirectly through interference with medication adherence. This is different from other studies which reported that neurocognitive impairment and depression are independent complications of HIV [44, 45]. This might be attributed to the fact that most of the participants had advanced HIV disease due to delayed treatment initiation.

Despite the strong link between depression and HAND, it is striking that there is no attention given to depression in the routine HIV care yet it is a serious psychiatric comorbidity in PLWH. Even mild depression could have deleterious consequences on the lives of PLWH. It can lead to inconsistent adherence, poor care engagement and ultimately to more serious outcomes [42]. Screening for depression among these people should be an integral part of the HIV care package so that it is appropriately managed. The untreated mental disorders work against the successful treatment of PLWH which has a great impact on health outcomes that affect the quality of life. It would also be important to study depression and neurocognitive disorders more rigorously comparing the HIV+ and HIV- cohorts. These screening tools required extensive staff training and time to be administered which was a limitation because the study was conducted within the daily activities of routine HIV care.

\section{Conclusion}

We found that depression was strongly associated with HAND which greatly affects the functioning of an individual. Our findings point to the importance of early recognition of depression and HAND as they are associated with increased rates of poor drug adherence and other poor outcomes including increased risky behaviours.

\section{Abbreviations}

4WR: Four word recall; AHS: Alternating hand sequence; AIDS: Acquired immune deficiency syndrome; ANOVA: Analysis of variance;

ART: Antiretroviral therapy; BDI: Beck depression inventory; CDDP: Community drug distribution point; CNS: Central nervous system; DSM-5: Diagnostic and statistical manual of mental disorders, fifth edition; FT: Finger tapping; HAND: HIV associated neurocognitive disorder; HIV: Human immunodeficiency virus; ICD: International statistical classification of diseases and related health problems; IHDS: International HIV dementia scale; MUST: Mbarara University of Science and Technology; NNRTI: Nonnucleoside reverse transcriptase inhibitor; PI: Principal investigator; PLWH: People living with HIV; PMTCT: Prevention of mother to child transmission; RA: Research assistant; REC: Research ethics committee; SSA: Sub Saharan Africa; TASO: The AIDS support organization; UNAIDS: United Nations agency for international development; UNCST: Uganda National council for science and technology; VCT: Voluntary counseling and testing 


\section{Acknowledgements}

We acknowledge study participants, research assistants and The AIDS Support Organization in Uganda who contributed to the success of this study. We also appreciate Mbarara University Research Training Initiative through which we received funding for this project.

\section{Authors' contributions}

JKN participated in designing the study, data collection, data analysis, and writing the manuscript. GZR designed the study, data analysis and participated in writing the manuscript. VN analyzed and interpreted data and contributed in manuscript writing. JGV contributed in designing the study, data analysis, and writing the manuscript. All authors read and approved the final manuscript.

\section{Funding}

The study was funded by the Fogarty International Center, the Office of the Director of the National Institutes of Health, the National Institute of Mental Health, and the National Institute of Neurological Disorders and Stroke under Award Number D43 TW010128. The content is solely the responsibility of the authors and does not necessarily represent the official views of the National Institutes of Health. The funder did not have any role in the design of the study and collection, analysis, and interpretation of data and in writing the manuscript.

\section{Availability of data and materials}

The datasets used and/or analyzed during the current study are available from the corresponding author on reasonable request.

\section{Declarations}

\section{Ethics approval and consent to participate}

We obtained ethical approval from Mbarara University of Science and Technology Research Ethics Committee (MUST-REC No. 27/10-16) and the Uganda National Council for Science and Technology (UNCST No. HS2194). We further got written authorization from the TASO Institutional Review Board.

The study was conducted in accordance with the Declaration of Helsinki. We protected the dignity, privacy and confidentiality of personal information of participants. The participants were requested to voluntarily participate, and were informed that they had a right to withdraw from the study at any time should they so wish. The participants gave written informed consent and were allocated identification numbers as a method of maintaining confidentiality.

\section{Consent for publication}

Not applicable.

\section{Competing interests}

The authors declare that they have no competing interests.

\section{Author details}

${ }^{1}$ Department of Nursing, Faculty of Medicine, Mbarara University of Science and Technology, Mbarara, Uganda. ${ }^{2}$ Department of Psychiatry, Faculty of Medicine, Mbarara University of Science and Technology, Mbarara, Uganda. ${ }^{3}$ Frances Payne Bolton School of Nursing, Case Western Reserve University, Cleveland, $\mathrm{OH}$ 44106, USA.

Received: 20 October 2020 Accepted: 7 May 2021

Published online: 12 July 2021

\section{References}

1. UNAIDS, On the fast-track to end AIDS by 2030: focus on location and population URL: http://www.unaids.org/sites/default/files/media_asset.WAD2 015_report_en_part01.pdf [accessed 2018-07-21] [WebCite Cache ID 715blMFf2], 2015.

2. Deeks SG, Lewin SR, Havlir DV. The end of AIDS: HIV infection as a chronic disease. Lancet. 2013;382(9903):1525-33. https://doi.org/10.1016/S0140-673 6(13)61809-7.

3. McArthur JC, Haughey N, Gartner S, Conant K, Pardo C, Nath A, et al. Human immunodeficiency virus-associated dementia: an evolving disease. J Neurovirol. 2003;9(2):205-21. https://doi.org/10.1080/13550280390194109.
4. Antinori A, Arendt G, Becker JT, Brew BJ, Byrd DA, Cherner M, et al. Updated research nosology for HIV-associated neurocognitive disorders. Neurology. 2007;69(18):1789-99. https://doi.org/10.1212/01.WNL.0000287431.88658.8b.

5. Haddow LJ, Floyd S, Copas A, Gilson RJC. A systematic review of the screening accuracy of the HIV dementia scale and international HIV dementia scale. PLoS One. 2013;8(4):e61826. https://doi.org/10.1371/journal. pone.0061826.

6. Namagga JK, Rukundo GZ, Voss JG. Prevalence and risk factors of HIVassociated neurocognitive disorders in rural southwestern Uganda. J Assoc Nurs AIDS Care. 2019;30(5):531-8. https://doi.org/10.1097/JNC. 0000000000000036.

7. Fialho RM, Pereira M, Mendonça N, Ouakinin S. Depressive symptoms and neurocognitive performance among HIV-infected women. Women Health. 2013;53(2):117-34. https://doi.org/10.1080/03630242.2013.767301.

8. American Psychiatric Association. Diagnostic and statistical manual of mental disorders (5th ed.). Arlington: 2013.

9. World Health Organization. The International Statistical Classification of Diseases and Health-Related Problems ICD-10, Tenth Revision. Volume 1: Tabular List (Vol. 1). World Health Organization; 2004.

10. Cross S, Önen N, Gase A, Overton ET, Ances BM. Identifying risk factors for HIV-associated neurocognitive disorders using the international HIV dementia scale. J Neurolmmune Pharmacol. 2013;8(5):1114-22. https://doi. org/10.1007/s11481-013-9505-1.

11. Atkinson JH, Heaton RK, Patterson TL, Wolfson T, Deutsch R, Brown SJ, et al. Two-year prospective study of major depressive disorder in HIV-infected men. J Affect Disord. 2008;108(3):225-34. https://doi.org/10.1016/j.jad.2007.1 0.017 .

12. Ickovics JR, Hamburger ME, Vlahov D, Schoenbaum EE, Schuman P, Boland RJ, et al. Mortality, CD4 cell count decline, and depressive symptoms among HIV-seropositive women: longitudinal analysis from the HIV epidemiology research study. Jama. 2001;285(11):1466-74. https://doi.org/10.1001/jama.2 85.11.1466.

13. Abas M, Ali GC, Nakimuli-Mpungu E, Chibanda D. Depression in people living with HIV in sub-Saharan Africa: time to act. Tropical Med Int Health. 2014;19(12):1392-6. https://doi.org/10.1111/tmi.12382.

14. Kingori C, Haile ZT, Ngatia P. Depression symptoms, social support and overall health among HIV-positive individuals in Kenya. Int J STD AIDS. 2015; 26(3):165-72. https://doi.org/10.1177/0956462414531933.

15. Memiah $P$, Shumba $C$, Etienne-Mesubi M, Agbor S, Hossain MB, Komba $P$, et al. The effect of depressive symptoms and CD4 count on adherence to highly active antiretroviral therapy in sub-Saharan Africa. J Int Assoc Providers AIDS Care. 2014;13(4):346-52. https://doi.org/10.1177/2325957413 503368.

16. Wroe EB, Hedt-Gauthier BL, Franke MF, Nsanzimana S, Turinimana JB, Drobac P. Depression and patterns of self-reported adherence to antiretroviral therapy in Rwanda. Int J STD AIDS. 2015;26(4):257-61. https:// doi.org/10.1177/0956462414535206.

17. Nel A, Kagee A. The relationship between depression, anxiety and medication adherence among patients receiving antiretroviral treatment in South Africa. AIDS Care. 2013;25(8):948-55. https://doi.org/10.1080/0954 0121.2012 .748867

18. Rubaihayo J, Tumwesigye NM, Konde-Lule J. Trends in prevalence of selected opportunistic infections associated with HIV/AIDS in Uganda. BMC Infect Dis. 2015;15(1):1.

19. Valcour $V$, Shikuma $C$, Shiramizu B, Watters $M$, Poff $P$, Selnes $O$, et al. Higher frequency of dementia in older HIV-1 individuals the Hawaii aging with HIV1 cohort. Neurology. 2004;63(5):822-7. https://doi.org/10.1212/01.WNL. 0000134665.58343.8D

20. Reynolds E. Benefits and risks of folic acid to the nervous system. J Neurol Neurosurg Psychiatry. 2002;72(5):567-71. https://doi.org/10.1136/jnnp.72.5. 567.

21. Katon WJ. Clinical and health services relationships between major depression, depressive symptoms, and general medical illness. Biol Psychiatry. 2003;54(3): 216-26. https://doi.org/10.1016/S0006-3223(03)00273-7.

22. McDowell I. Measuring health: a guide to rating scales and questionnaires. USA: Oxford University press; 2006.

23. Chan C-M, Tsoi MM. The BDI and stimulus determinants of cognitive-related depression among Chinese college students. Cogn Ther Res. 1984;8(5):5017. https://doi.org/10.1007/BF01173287.

24. Andrade L, Gorenstein C, Vieira Filho AH, Tung TC, Artes R. Psychometric properties of the Portuguese version of the state-trait anxiety inventory 
applied to college students: factor analysis and relation to the Beck depression inventory. Braz J Med Biol Res. 2001;34(3):367-74. https://doi. org/10.1590/50100-879X2001000300011.

25. Gorenstein C, Andrade L. Validation of a Portuguese version of the Beck Depression Inventory and the State-Trait Anxiety Inventory in Brazilian subjects. Braz J Med Biol Res. 1996;29(4):453-7.

26. Tusiime J, Bangsberg D, Mark W. Examining the psychometric properties of the Beck depression inventory-ii using an item response Modelling approach in an HIV infected population in Kampala, Uganda. J Depress Anxiety. 2015:4(184):2167-1044.1000184.

27. Beck AT, et al. An inventory for measuring depression. Arch Gen Psychiatry. 1961;4(6):561-71. https://doi.org/10.1001/archpsyc.1961.01710120031004.

28. Beck AT, Steer RA, Carbin MG. Psychometric properties of the Beck depression inventory: twenty-five years of evaluation. Clin Psychol Rev. 1988; 8(1):77-100. https://doi.org/10.1016/0272-7358(88)90050-5.

29. Sacktor NC, Wong M, Nakasujja N, Skolasky RL, Selnes OA, Musisi S, et al. The international HIV dementia scale: a new rapid screening test for HIV dementia. Aids. 2005;19(13):1367-74.

30. Nakku J, Kinyanda E, Hoskins S. Prevalence and factors associated with probable HIV dementia in an African population: a cross-sectional study of an HIV/AIDS clinic population. BMC Psychiatry. 2013;13(1):1.

31. Kagee A, Martin L. Symptoms of depression and anxiety among a sample of south African patients living with HIV. AIDS Care. 2010;22(2):159-65. https:// doi.org/10.1080/09540120903111445.

32. Passos SMK, Souza LDDM, Spessato BC. High prevalence of suicide risk in people living with HIV: who is at higher risk? AIDS Care. 2014;26(11):137982. https://doi.org/10.1080/09540121.2014.913767.

33. Silveira MPT, Guttier MC, Pinheiro CAT, Pereira TVS, Cruzeiro ALS, Moreira LB. Depressive symptoms in HIV-infected patients treated with highly active antiretroviral therapy. Braz J Psychiatry. 2012;34(2):162-7. https://doi.org/10.1 590/S1516-44462012000200008

34. Clarke DM, Currie KC. Depression, anxiety and their relationship with chronic diseases: a review of the epidemiology, risk and treatment evidence. Med J Aust. 2009;190(S7):S54-60. https://doi.org/10.5694/j.1326-5377.2009.tb02471. $x$.

35. Ford DE, Erlinger TP. Depression and C-reactive protein in US adults: data from the third National Health and nutrition examination survey. Arch Intern Med. 2004;164(9):1010-4. https://doi.org/10.1001/archinte.164.9.1010

36. Cyranowski JM, Frank E, Young E, Shear MK. Adolescent onset of the gender difference in lifetime rates of major depression: a theoretical model. Arch Gen Psychiatry. 2000;57(1):21-7. https://doi.org/10.1001/archpsyc.57.1.21.

37. Gillies GE, McArthur S. Estrogen actions in the brain and the basis for differential action in men and women: a case for sex-specific medicines. Pharmacol Rev. 2010;62(2):155-98. https://doi.org/10.1124/pr.109.002071.

38. Young Y, Frick KD, Phelan EA. Can successful aging and chronic illness coexist in the same individual? A multidimensional concept of successful aging. J Am Med Dir Assoc. 2009;10(2):87-92. https://doi.org/10.1016/j.ja mda.2008.11.003.

39. Vance DE, et al. Successful aging and the epidemiology of HIV. Clin Interv Aging. 2011;6:181.

40. Johnsson G. Management of mental health disorders in HIV-positive patients: by the southern African HIV clinicians society. S Afr J HIV Med. 2013;14(4):155-66.

41. Nyirenda M, Chatterji S, Rochat T, Mutevedzi P, Newell ML. Prevalence and correlates of depression among HIV-infected and-affected older people in rural South Africa. J Affect Disord. 2013;151(1):31-8. https://doi.org/10.1016/j. jad.2013.05.005.

42. So-Armah K, Gupta SK, Kundu S, Stewart JC, Goulet JL, Butt AA, et al. Depression and all-cause mortality risk in HIV-infected and HIV-uninfected US veterans: a cohort study. HIV Med. 2019;20(5):317-29. https://doi.org/1 0.1111/hiv. 12726.

43. Skinner S, Adewale AJ, DeBlock L, Gill MJ, Power C. Neurocognitive screening tools in HIV/AIDS: comparative performance among patients exposed to antiretroviral therapy. HIV Med. 2009;10(4):246-52. https://doi. org/10.1111/j.1468-1293.2008.00679.x.

44. Belete T, Medfu G, Yemiyamrew E. Prevalence of HIV associated neurocognitive deficit among HIV positive people in Ethiopia: a cross sectional study at Ayder referral hospital. Ethiop J Health Sci. 2017;27(1):6776. https://doi.org/10.4314/ejhs.v27i1.9.

45. Lawler K, Mosepele M, Seloilwe E, Ratcliffe S, Steele K, Nthobatsang R, et al. Depression among HIV-positive individuals in Botswana: a behavioral surveillance. AIDS Behav. 2011;15(1):204-8. https://doi.org/10.1007/s10461009-9622-2.

\section{Publisher's Note}

Springer Nature remains neutral with regard to jurisdictional claims in published maps and institutional affiliations.

\section{Ready to submit your research? Choose BMC and benefit from:}

- fast, convenient online submission

- thorough peer review by experienced researchers in your field

- rapid publication on acceptance

- support for research data, including large and complex data types

- gold Open Access which fosters wider collaboration and increased citations

- maximum visibility for your research: over $100 \mathrm{M}$ website views per year

At $\mathrm{BMC}$, research is always in progress.

Learn more biomedcentral.com/submissions 